INTERNATIONAL JOURNAL OF RESEARCH IN SOCIAL SCIENCES \& HUMANITIES

An International Open-Access Peer Reviewed Referred Journal

\title{
INTELLECTUAL PROPERTY RIGHTS AND ITS IMPLICATIONS FOR THE PHARMACEUTICAL INDUSTRY IN IRAQ UNDER ACCESSION TO THE WORLD TRADE ORGANIZATION
}

Assist. Prof. Dr. Sabah Neama Ali, M Dalia Omar Nazmi, Dr Yousif Aftan Abdullah

College of Administration \& Economics, University of Baghdad, Iraq Republic of Iraq Ministry of Higher Education and Scientific Research, Iraq

DOI: http://doi.org/10.37648/ijrssh.v12i01.004

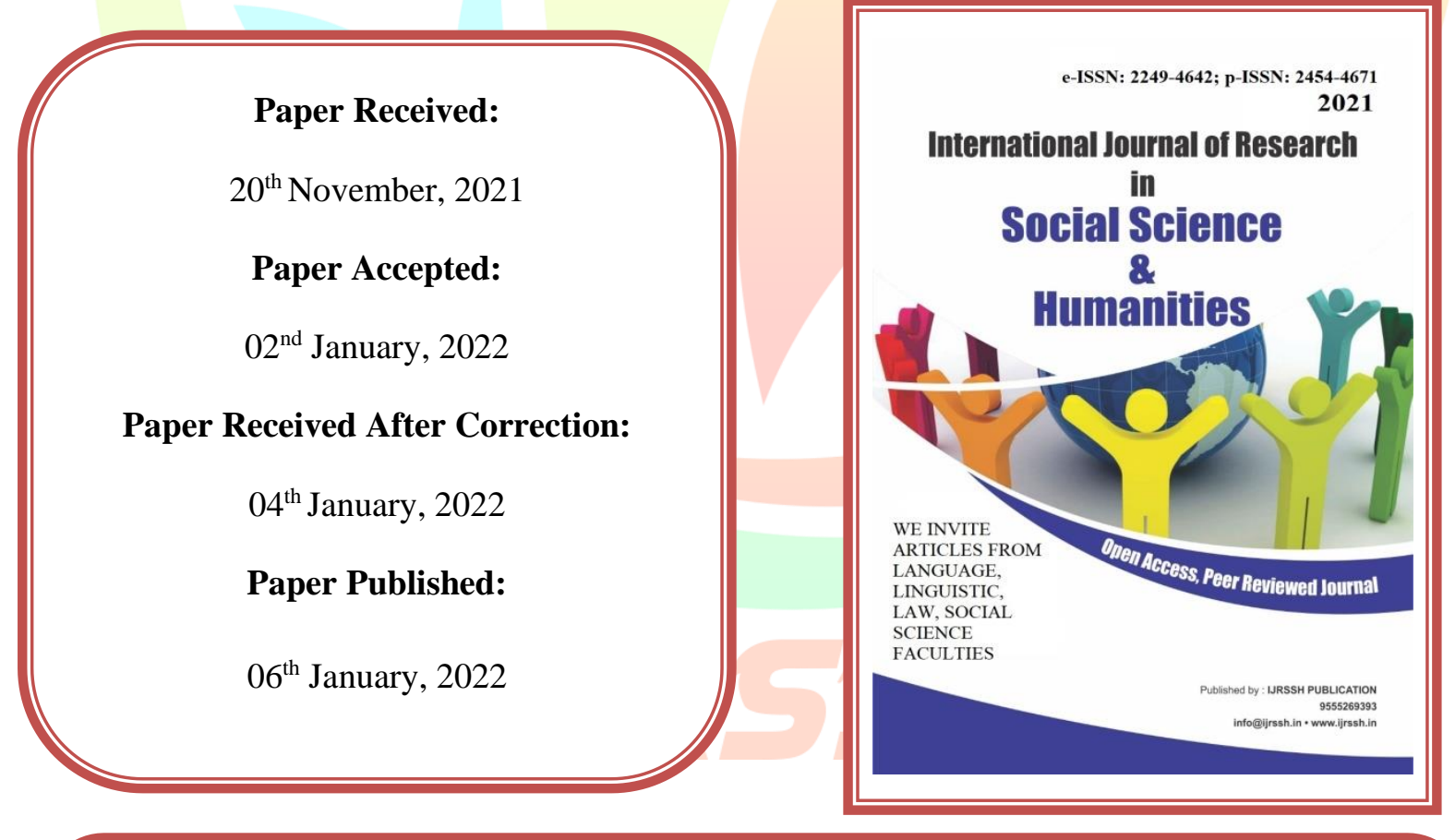

How to cite the article: Dr. Sabah Neama Ali, M. Dalia Omar Nazmi, Dr. Yousif Aftan Abdullah, Intellectual Property Rights and its Implications for the

Pharmaceutical Industry in Iraq Under Accession to the World Trade Organization, January-March 2022 Vol 12, Issue 1; 57-76 DOI: http://doi.org/10.37648/ijrssh.v12i01.004 


\begin{abstract}
The main risks arising from the WTO Agreement are the inequality and lack of competitiveness of most pharmaceutical goods, as well as the fact that Iraq is a net importer of medicines that are at the core of consumer needs, The subject matter of the Convention on the Protection of Intellectual Property Rights and its implications for the pharmaceutical industry, in particular, coinciding with the situation of financial and administrative corruption, all of which has resulted in drug fraud in the Iraqi market and its impact on public health. The control of medical technology, the persistence of the technological gap and its effects on high price levels, and the fact that domestic drug producers are obliged to obtain production licenses from global companies in the light of limited access to pharmaceutical research and development. The research aims at the impact of economic liberalization within the World Trade Organization (WTO) and its negative effects on consumers by highlighting the economic and social effects on consumption by raising prices and monopolies and restricting the volume of consumer demand because of the loss of the competitive advantage of pharmaceutical goods. Iraq's unwillingness to accede to the International Convention for the Protection of Intellectual Property Rights of the World Trade Organization (WTO) and the deterioration of the pharmaceutical industry meant increased dependence on the outside, increased trade deficits, higher price levels, and its adverse effects on consumers. Iraq finds it difficult for developed countries to use their intellectual rights as well as restrict industrial and agricultural work because production and production methods are now subject to their intellectual property protection law, which prevents any possible industrial development. The most significant potential short-term impact of TRIPS is the decline in drug production, which continues to be protected. The great challenge for drug producers is the need to obtain licenses from parent companies because of limited R \& D potential. In the long run, the negative effects of TRIPS will be greater than in the short term, as they will create a major challenge for Iraqi pharmaceutical companies, namely, the need to obtain production licenses from parent companies to produce protected medicines. However, limited R \& D potential for local firms The small size of the domestic market and the high cost of production discourages global companies from entering into alliances with Iraqi pharmaceutical companies. This reduces the potential for achieving the desired benefit of the TRIPS Convention for developing countries, including Iraq, by encouraging and attracting global investment to these countries. The mechanisms of the system of international relations, in particular the Monetary Fund, the World Bank, and the World Trade Organization (WTO), have brought debtor countries under the control of creditor States and have imposed economic and social costs on them as a result of adapting to global trends. However, the growing interdependence and interdependence of the world economy
\end{abstract}




\section{Volume: 12, Issue: 1, January-March 2022}

have led to increased risks and the spread of economic and financial crises and to the departure of globalization mechanisms from finding solutions to the economic and social problems of poor countries. review trade, investment, and exchange rate laws and reform legal, administrative, and financial systems. Priority should be given to strengthening the functional structure and combating economic crime and industrial and commercial fraud. Support, protection, and State sponsorship of domestic pharmaceutical industries, development of appropriate policies, and attention to market research to counter the negative effects of the WTO Convention and intellectual property protection laws. and the establishment of research and development centers to control drug technology, which will lead to capacity development to enhance competitive advantage, taking into account the importance of improving the quality and quality of products, their technical specifications, and their alignment with global changes.

Keywords: Intellectual Property Rights, Pharmaceutical industry, World Trade Organization 


\section{Volume: 12, Issue: 1, January-March 2022}

\section{INTRODUCTION}

The research examined the major risks arising from the WTO Convention in the context of the inequality and lack of competitiveness of most pharmaceutical goods, as well as the fact that Iraq is a net importer of medicines that are at the core of consumer needs. Iraq's unwillingness to accede to the International Convention on the Protection of Intellectual Property Rights of the World Trade Organization (WTO) and the deterioration of the industrial sector, particularly pharmacology, meant increased dependence on the outside, increased trade deficit, and higher price levels, and the adverse effects that it would have on consumers.

The research also illustrated the subject matter of the Convention on the Protection of Intellectual Property Rights and its implications for the pharmaceutical industry, in particular, in conjunction with the financial and administrative corruption situation, all of which resulted in drug fraud in the Iraqi market and its impact on public health. This Convention covers broad areas and activities, in particular patents, industrial secrets, trademarks, copyright, and copyrights, which represent monopoly advantages for developed countries. It will lead to the control of medicine technology and the persistence of the technology gap. In addition to its effects on high price levels, to restrict economic activities in the areas covered by this Convention, domestic drug producers are obliged to obtain licenses from global companies in the light of limited access to pharmaceutical research and development, and the fact that the Iraqi market is dumping corrupt and misguided medicines in the absence of periodic and monthly monitoring and the proliferation of what is known today as the shadow economy operating in the informal or unregulated context and authorized to sell medicines.

The research aims to demonstrate the impact of economic liberalization within the World Trade Organization (WTO) and its negative effects on consumers by highlighting the economic and social damage to consumption by raising prices and monopolies and restricting the volume of consumer demand in the light of the loss of the competitive advantage of pharmaceutical goods. In addition, the Agreement on the Protection of Intellectual Property Rights, which was entered into by developed countries in the World Trade Organization (WTO), provides a higher level of protection against patents and trademarks held by developed countries, all of which reflect negative effects on the economies of developing countries, including Iraq in particular, and on the pharmaceutical 


\section{Volume: 12, Issue: 1, January-March 2022}

industry, given the growing scientific and technological gap and the impact of the Convention on consumers.

FIRST, THE PHARMACEUTICAL AND COMMERCIAL INDUSTRIAL CIRCUMVENTION IN THE IRAQI MARKET

1- Circumventing legal norms in pursuit of an unlawful objective that falls within the framework of various types of offenses relating to this subject, such as industrial and commercial tax fraud, election fraud, and intellectual and artistic thefts. It also includes counterfeiting, copying, or manufacturing of objects intending to harm those entitled to manufacture them, such as counterfeiting money or imitating seals, trademarks, or patents. Oman, Charles, Globalization and Regionalization, The Challenge For Developing Countries OCED,1994, P 27

2- Scholars have striven to define cheating. Those who define it as any change to the goods either by changing the elements involved in them, by confusing them with other products, or by changing their true shape without the beneficiary's knowledge of it and those who have defined it as making a product that is different from the fact of the original production on terms inconsistent with professional regulations, instructions or usages. The Iraqi draft resolution on combating industrial fraud provided first for the definition of industrial fraud as an act that would result in the production and marketing of a substance contrary to the rules adopted in its industry and would diminish its characteristics and benefits.

- Brand imitation.

- Non-acquisition of official production approvals and installation of data, visas, or marks that do not correspond to actual or planned components of the product.

- Use of product additives or pigments to harm the consumer.

- To hide, change or remove the original production or entry date of the product, or repackage or packaging of the finished or finished product with new packaging bearing a different production and entry date and change the shipping documents of imported products.

- The production and marketing of material with components that are completely different from the material whose name, components, or trademark is proven.

The main causes of drug fraud in Iraq include:

1- Shift towards a market economy without specific rules or controls (Mahmoud, 2001: 274-280), whereby commercial liberalization and the opening of borders to various medicines, regardless of their validity, conformity with technical 


\section{Volume: 12, Issue: 1, January-March 2022}

standards and specifications or certificate of origin.

2- Iraq suffers from control regimes that do not comply with monthly or periodic monitoring as required.

3- The lack of laws to protect intellectual property rights related to the trade in medicines, particularly those relating to trademarks, industrial secrets, and geographical references.

4- The emergence of an unregulated economy or what is known as the informal sector for the sale and marketing of medicines, where there is no license to engage in such activity, is not subject to legal fees and is not subject to labor law, as well as ease of entry into and exit from economic activity, whether productive or professional.

5- Acute shortages of commodity supply of medicines and heavy import dependence.

6- The World ISO Quality System does not apply any technical and environmental specifications for the production and trade of medicines to reduce commercial and industrial fraud. The Quality Specification Authority shall establish rules and mechanisms for the application of this System by the circumstances and needs of investment and industry, thereby ultimately achieving the results it targets and requiring that international standards and certification be followed.
7- There are numerous border entry points for goods, with some 23 border outlets with neighboring States that are difficult to control with administrative and financial corruption.

8- Failure to request the guarantees of pharmaceutical manufacturers by the relevant authorities that are usually attached to these products, or registration of the product number on the company's website. In the absence of specialized supervision of the quality of goods, the fight against fraud, counterfeiting, and misinformation, and the fact that it is not possible to open workshops to examine the equipment and parts to maintain the quality and quality of the local market, maintain investments in it and combat fraud, have led to the continuation of operations that have depleted and affected the market and society.

9- The enforcement and existence of largescale commercial and industrial fraud and the easy flow of medicines to markets, consumer misinformation, and the promotion of medicines because of the low purchasing capacity experienced by the Iraqi consumer, take a low price regardless of quality. 


\section{Volume: 12, Issue: 1, January-March 2022}

\section{SECOND: $\quad$ WORLD TRADE ORGANIZATION AND ITS IMPLICATIONS FOR CONSUMER PROTECTION}

The emergence of international organizations after the Second World War to spread capital ideas, sustain the continuity of the system, and restructure the global system in terms of investment and trade according to market standards, thereby promoting the building of industrial and technological bases and the building of the development. The capital will be won by the establishment of an international trading organization whose objectives included the removal of restrictions and obstacles to the movement of goods and services. GATT is based on the stated principle of preference for multilateral agreements over bilateral agreements whereby several successive reductions in quantitative and tariff restrictions on trade have been made in many rounds, most recently in around. (Uruguay), which covered various aspects of the scope of those reductions, in particular agricultural goods and services. Kevin, Clarer, The Impact of Price and Export Rate Policies on Africa in SubSahara Africa, World the Marrakesh Agreement requires all signatory States to accept all conventions without exception.

The lifting of tariff restrictions and trade quotas, the utilization of low labor wages, and the creation of a climate for foreign direct investment have allowed the entry of the most productive firms to allow the capitalist system to dominate global markets. The mutual relationship between trade liberalization and the adaptation of domestic economies to the global environment was formed. The real foundations were laid for creating an international environment that would allow capital, goods, and services to move easily between the countries of the world.

* Challenges of Iraq's accession to the World Trade Organization and its negative consumer implications

The World Trade Organization (WTO) allows the use of some instruments that limit free trade, such as emergency protection, anti-dumping and countervailing duties, which are important exceptions that developed countries can use in cases of harm to developing countries, which are the strongest players in the face of products exported by developing countries while developing countries do not allow them to exercise and apply these exceptions to reduce import demand flexibility and their urgent need for various types of goods as they undertake development projects or 1- WIPO has been interested in the subject of the Convention on the Protection of Intellectual Property Rights, Developing countries, in particular Iraq, which need 


\section{Volume: 12, Issue: 1, January-March 2022}

technology or expertise in the pharmaceutical industry, will only have to participate in foreign investment with title and other control over market activities and excessive prices. The high cost of development programs as a result of the application of intellectual property rights agreements increases the cost of importing technology and the costs of using labels, copyrights, and software, as well as the higher costs of production due to the high price of inputs from imported products, as well as the potential rise in wages due to the rise in the price of food and medicine and the harmful effects on consumers))Thurow Lester, The Future Of Capitalism, Penguin Books, New York, 1997, p 128.

The negative impact on economic activity in general and on production and employment in some areas where developing countries' markets, such as services and certain industrial products, will be opened up as a result of uneven competition in quality or quality, the magnitude of costs to which they will be exposed by foreign sources and the destruction of national industry and service activity, which means that there are few opportunities to use production components and although this will provide greater choices for consumers, In the long run, however, this will drive the trend of unemployment, lower incomes of production components and, consequently, lower consumption in general as a result of lower incomes of individuals because of the curtailment of the role of the State and IMF prescriptions. The misuse by industrialized countries of rules of preventive action, anti-dumping and technical restrictions on specifications and quality impede the entry of some developing countries' exports into their markets.

$2^{\mathrm{ND}}$-Iraq's capacity to design its development policies is reduced. The WTO Convention implies the transfer to the Organization of a lot of national decision-making powers in several areas, in particular concerning foreign investment, which prevents the foreign enterprise from being bound by export, import, or domestic objectives, as well as the subject matter of the Convention on Intellectual Property Rights and the determination of the types of permitted and prohibited subsidies.

THIRD: PROTECTION OF INTELLECTUAL PROPERTY

\section{RIGHTS - THEIR IMPLICATIONS}

The interest in intellectual protection emerged in the wake of the eighth round of forestry, where an agreement on traderelated intellectual property rights was signed. One of its most important reasons is that it aims to advance economic 


\section{Volume: 12, Issue: 1, January-March 2022}

progress by rewarding researchers and innovators to invest in $\mathrm{R} \& \mathrm{D}$ on the one hand and encouraging investors to finance and encourage $\mathrm{R} \& \mathrm{D}$ on the other. The Convention established specific standards for the protection of patents, brand names, trade-in copycat goods, and unauthorized confidential information. It thus prevents imitation of the production method and brand to prevent imitation of the final or intermediate product, since simply changing the name of the commodity does not mean that it is different. After the formation of the WTO, TRIPS and other side conventions are the basis of the WTO, so accession to WTO requires adherence to all side agreements (Abdelhay, oppressed, 1999:228).

\section{A: Highlights of the Convention} on Property Rights TRIPS

The Convention on Property Rights TRIPS on Trade in Goods and Services under the World Trade Organization (WTO) is the most comprehensive and relevant multilateral agreement, both for its coverage, provisions, member States, and its first-ever dispute settlement mechanism. The Convention was reached through intensive and complex negotiations in the Uruguay Round of multilateral trade negotiations.

The Convention entered into force on 1 January 1995 and during transitional periods varied according to the level of economic growth prevailing in member States and covered various types of intellectual property rights (copyright, associated rights, trademarks, industrial designs, patents, complete circuits, undisclosed trade secrets) (Birch, Marzouk, 1999:89).

\section{B: Motives behind the adoption}

\section{of the Convention on Property Rights}

The main motivations behind the adoption of the Convention on Intellectual Property Rights by industrialized countries, home to the invention, research, and development, are that they now possess monopoly comparative advantages in terms of the relative superiority of the scope of know-how, the entry of new products with advanced technological levels into international markets and their desire to retain their competitive position so that they become the sole source of technology-intensive goods, to maintain this technology gap and not be so temporary that today most goods can be produced by other countries. (Copycat) Through their success in the area of technology transfer or imitation, by removing this monopoly, the technological superiority of these countries will no doubt cease, especially when the production process takes shape, the production states of new goods become similar between states and as a result, the technological component loses its important role as an 


\section{Volume: 12, Issue: 1, January-March 2022}

explanation for the pattern of foreign trade between states in this type of product and can be relied upon.

Determining the technology gap using the following diagram showing production and export according to the technology gap model through the use of the demand gap and the tradition gap. The demand gap means the period between the emergence of the production of a commodity in the life cycle of the commodity (product) in the country of the invention (T1) and the beginning of consumption of the commodity in External (T2) In light of this, the technological gap of trade can be defined as a function of the time limit between the demand gap (T1-T2) and the tradition gap (T1-T3) as "such trade occurring during the time beginning with the export of the product or the new commodity by the inventing State and the beginning of production of the commodity in the States that are imitating the commodity of interest." Technological factors begin to lose the role they have played as an explanation for the pattern of foreign trade between States in technologically intensive industrial products and are replaced by the abundance and relative scarcity of natural production elements and the existence of foreign trade. The rules are applied under the Hexer-Olin theory of factor ratios.
Differences between international wage levels can be said to be an important determinant of the length of time taken by the technology gap and of the resulting foreign trade. Accordingly, technological developments in the form of inventions or renovations may quickly pass home to other States where there are low wage levels for this State that allow for the production of a commodity with lower production expenses than in the home State. (Traveller, Yassin, 2002: This trend has helped to demonstrate the important role played by multinational corporations in the development of foreign trade between States and their investments outside the home State to reduce their production expenditures and thereby increase their competitiveness, especially if wages play a role in determining production expenditures.

This would highlight the motives for many multinational corporations to invest part of their capital in developing countries to exploit the cheap labor available in those countries. That means that exports of manufactured goods remain dependent on what they allow without the possibility of developing and replacing imported technology with domestic capabilities and making them dependent on the exploitation of foreign patents, whether by purchasing, licensing, handing over the key, technical assistance, or joint 
investment. (Technology transfer with subcognitive physical side), which leads to the continued weakness of technological capabilities in manufactured goods where production costs are high (by investing, operating, and relying on foreign sources for spare parts and low labor productivity) In addition to the continued inability to efficiently operate imported technologies in most developing countries, this is due mainly to lack of technology uptake, low skill, training, administrative and management problems and periodic maintenance (ESCWA, 1999:In addition to the continued near-complete reliance on foreign companies and contractors in the various stages of the creation and operation of production units from the selection phase and the preparation of feasibility studies to the construction, training, operation and maintenance phases, which means the survival and continuation of technological dependence, which is part of the economic and political dependence of the outside world. We, therefore, conclude that the Convention on Intellectual Property Rights aims to tighten control over international trade routes on the one hand and to restrict development paths in the developing world on the other, by limiting and benefiting from technology transfers and by eliminating mainly dependent manufacturing processes. (Tradition) thus creating additional costs for developing countries in their pursuit of industrial growth and in reducing their economic utilization.

\section{FOURTH: EFFECTS OF THE CONVENTION ON THE}

PROTECTION OF INTELLECTUAL PROPERTY ON THE COURSE OF THE IRAQI PHARMACEUTICAL AND CONSUMER INDUSTRY

\section{A: Economic implications}

In its content, the Convention made it clear that it contributes to the promotion of innovation, technology, and technology transfer and diffusion for the common benefit of technology producers and users. However, the Convention has resulted in the continuation of the state of technical and technological dependency and the maintenance of the technical difference between it and developing countries, as well as the continued brain leaks into the developed industrial world, making it a place for the recording of scientific innovations and discoveries. This is not included in the Convention but focuses only on trade aspects relating to goods. However, the international trend of globalization and the association of countries with a network of communications and information has opened the way for those interested in the acquisition, circulation, and production of 


\section{Volume: 12, Issue: 1, January-March 2022}

technologies locally. There have been many experiences of developing countries being able to carry out the process of industrialization by imitating and developing products, as well as the importance of technology as a determinant of global competitiveness. This background has been behind the advanced State's lobbying for multilateral action to establish international protection of intellectual property rights $(\mathrm{Z}$, beauty of debt, 2001).

In the view of developed States, intellectual property rights granted amount to protection, As set out in the section of Article 9 to Article 40, it must reflect the economic balance between the substantial investments that Governments and companies devote to research and development and the economic benefits derived from the commercialization of these achievements and innovations, Thus, in seeking to impose global discipline on intellectual property, they have been able to secure their companies the right to receive substantial revenues for their research, noting that the industrialized countries lose tens of billions of dollars a year because of the presence of copycat goods in world trade So these countries have better ways to fight the imitation and counterfeiting of many goods, especially in Asia and Latin America. Thus, global pharmaceutical and pharmaceutical companies will gain more leverage for imposing patent rights and protecting their licenses, especially in developing countries such as Iraq.

They also give protection to biological products and their methods, which will mean a restriction on some agricultural activities in many countries and a rise in the price of agricultural inputs and seeds. This will contribute to a decline in agricultural productivity and income of farmers and will create important problems, especially since the agricultural sector is the most important for the economies of developing countries. Large biotech companies believe that their massive investments in research, particularly in plant and animal genetic engineering, have yielded significant results in terms of plant and animal species. They have been able to protect their scientific achievements and have succeeded in doing so through the World Trade Organization (WTO) Convention on the Protection of Their Intellectual Rights. This means that farmers in developing countries who have been able to obtain many varieties of seeds that fit their domestic needs have become vulnerable.

Large global companies that dominate markets for goods and services products will also be able to tighten control of markets for goods, food, and seeds in other States under the pretext of intellectual 


\section{Volume: 12, Issue: 1, January-March 2022}

property rights. Moreover, domestic laws in many developing countries, including Iraq, of course, do not fit into the provisions of the Convention in terms of the titles protected or other actions to be taken by the State, as they may face problems in reforming their intellectual property laws or in enforcing their laws.

The WTO Convention and its intellectual property rights relating to trade in goods and services have an impact on the manufacturing movement, as they will increase manufacturing costs, particularly the pharmaceutical industry, owing to high patent prices, as well as technological monopolies, which will adversely affect the food industry given significant developments in biotechnology at the food manufacturing level, as well as the high prices of the pharmaceutical, electronic and petrochemical industries. (General Secretariat of the General Federation of Arab Chambers of Commerce, Industry and Agriculture, Journal of Economic Papers, No. 15, 2000, p. 250).

For Iraq, the provisions of this Convention also do not contain anything that would facilitate the transfer of technology, if not the other way around in making this more difficult and at least more expensive. Although supporters of the Agreement (technology exporters) justify this Convention as contributing to promoting the transfer and development of technology domestically, increasing productivity, competition and income.

In addition, Iraq will find it difficult for developed countries to use their intellectual rights, as well as to restrict industrial and agricultural work because production and production methods are subject to their intellectual property protection law. This prevents any possible industrial or other development by facilitating the flow of technology transfer at the international level. In addition, there are financial costs in terms of preparing those responsible for the implementation of the Agreement and financing the efforts and capacities of local professionals, which are limited in number from the development of the technique and to the investigation of the proper application of the terms of the Agreement (El Quraishi, Ilol200:208-209).

It can be said that the negative effects that the Convention on Intellectual Property Rights may have on the economy and the industrialization movement in Iraq will, as a whole, affect consumers in difficult health conditions and the protection of their rights.

\section{B: Possible implications for the} pharmaceutical industry and the protection of the Iraqi consumer

1- Adherence to TRIPS principles requires companies in member States to stop producing or using the brand name of 


\section{Volume: 12, Issue: 1, January-March 2022}

protected medicines. TRIPS protection in the pharmaceutical industry may be up to 20 years, so the use of property rights plays a key role in the pharmaceutical industry at present and a larger role in the future, and the TRIPS Convention requires adherence to the following international conventions (2000-209):

2- - The Paris Convention for the Protection of Industrial Property.

3- - The Berne Convention for the Protection of Literary and Artistic Works.

4- - Rome Convention for the Protection of Artists, Business Producers, and Research Institutions.

5- The application of these conventions requires the amendment of existing laws or the enactment of new laws that meet the requirements and requirements of the various conventions. The question is the impact of TRIPS on the pharmaceutical industry in developing countries, including Iraq. Some argue that the Convention will achieve positive results for developing countries by attracting foreign investment. Some argue that the Convention will harm the pharmaceutical industry in developing countries. However, there are many indications that the Convention will increase the price of medicines, thereby reducing the welfare of society in the foreseeable term. through their impact on domestic production, the cost of medicines, and their provision to the consumer, The importance of these effects varies from country to country based on the market structure, i.e. the pre-entry status of the Convention in terms of production and technology and the status of competition and monopoly conditions that will arise after entry into the Convention. and supply and demand for protected medicines. Also, the number of medicines to be protected and their share of drug consumption under the legal frameworks that determine the conditions for licensing if granted. in addition to the availability and effectiveness of government programs to help companies adapt to new legal regulations and legal frameworks available to combat monopolistic behavior resulting from the granting or non-granting of licenses. The problem would arise after the entry into the Convention in the event of a desire to produce new items that would enjoy intellectual protection, which would require a license from the manufacturer's parent company. The most important possible short-term effects of TRIPS are (Zinni, 342009):

1- The decline in pharmaceutical production of still protected medicines is a major challenge for drug producers, which is the need to obtain licences from parent companies in view of limited $\mathrm{R} \& \mathrm{D}$ 
potential.

2- Restrictions on importers, distributors and drug warehouses in that they have to deal with the patent holder or his representative and thus stop importing and distributing drugs that do not comply with TRIPS. This will reduce import opportunities and outlets as demand for medicines increases.

2- The increase in the price of protected medicines due to the increased monopoly power of the patent holder, increased reliance on external medicines and thus increased import and subsequent negative effects on the economy. and monopoly powers resulting in higher prices for goods and services due to high levels of protection of intellectual property rights, with continued increased dependence on the outside and subsequent persistent trade deficit and health security i. Restrictions on export prospects as TRIPS signatories refuse to register and import any imported drug if a producer does not adhere to TRIPS. 4- The consolidation and hegemony of developed countries and their acquisition of monopolistic benefits in exchange for the acquisition by developing countries, including Iraq, of some of their intellectual products and their uses in the light of the migration of skills and scientists to developed countries. 5- The demand for the drug is considered inflexible by the consumer, that is, a rise in drug prices will not affect the quantity required. The amount required to respond to the change in the high price is equal to zero because of the drug's strategic importance.

To minimize adverse effects, there are gaps in the Convention in general that could be used to delay the application of the terms of the Agreement (Macdadi, 2000:56):

1. The Introduction to the Convention notes that developing States have their own needs and circumstances, however, they are given an entry point to claim additional advantages from the Convention.

2. Article 7 of TRIPS states that intellectual property protection must lead to greater industrial progress and information transfer, and any State can challenge TRIPS if it can demonstrate its commitment to TRIPS will deprive it of industrial progress and information transfer.

3. Article 8 of TRIPS allows the Member States to amend their laws to protect public health, enabling States to delay the implementation of the Convention if they can demonstrate that the implementation of the Convention will be detrimental to public health if the price of protected medicines increases and this is detrimental to public health. The second part of this 


\section{Volume: 12, Issue: 1, January-March 2022}

article also calls for TRIPS not to be a means of impeding trade, which may happen in the event of high drug prices.

4. Article 27 of TRIPS gives some exceptions in registering inventions that may be harmful to public health, through higher prices of protected medicines.

5. Article 30 of TRIPS allows a Member State to make certain exceptions that are not unreasonable to the ordinary exploitation of the legitimate rights of the patent owner, as they may resort to socalled compulsory licensing. 6. Article 31 (k) of TRIPS allows monopoly market conditions to be taken into account when assessing the amount of compensation due to the patent owner.

6. Article 12 of the 1994 GATT allows for certain exceptions in the case of a balanceof-payments deficit. These exceptions include medicines, as higher prices for imported medicines will increase the trade deficit.

In the long term, however, the negative effects of TRIPS will be greater than in the short term, as they will create a major challenge for Iraqi pharmaceutical companies, namely, the need to obtain production licenses from parent companies for the production of protected medicines. Options for action (2012), pp.) However, the limited R \& D potential of local firms, the small size of the domestic market, and the high cost of production do not encourage global companies to enter into alliances with Iraqi pharmaceutical companies. This reduces the potential for achieving the desired benefit of the TRIPS Convention for developing countries, including Iraq, by encouraging and attracting global investment to these countries. The pharmaceutical industry is characterized by a high dependence on science and technology, as is the space and electronics industry, with a research and development intensity of $20 \%$ of sales to some global companies and $9 \%$ of the value of pharmaceutical production in OECD countries.

What characterizes the pharmaceutical industry is that the cost of R \& D is very high and its economic yield is uncertain, as these factors create significant barriers for small companies so that they are reluctant to do intensive $\mathrm{R} \& \mathrm{D}$ and thus reduce their opportunities for creativity and excellence. Areas of research and development include the development of new pharmaceutical compounds, the improvement of the quality and effectiveness of certain medicines in circulation, the development of production processes, and the improvement and development of medical preparations.

\section{CONCLUSIONS}

1- The mechanisms of the system of international relations, in particular the 


\section{Volume: 12, Issue: 1, January-March 2022}

Monetary Fund, the World Bank, and the World Trade Organization (WTO), have led to debtor countries being controlled by creditor States, transformed into dependent peripheral societies, imposed high socioeconomic costs on them by adapting to global trends, reflected negatively on consumers and had to be protected by the beginner of the United Nations.

2- Reducing barriers to international trade and competition and benefiting from the diffusion of technology and production activities in the context of globalization, However, the growing interdependence and interdependence of the world economy have led to increased risks and the spread of economic and financial crises. The mechanisms of globalization have moved away from solving the economic and social problems of poor countries and away from the concepts of development and sustainable consumption, where poverty, unequal distribution of wealth and income, and underdevelopment have a significant impact on consumers. Globalization is ending the role of the State in welfare and social security.

3- Entry into the World Trade Organization (WTO) means the entry of domestic industry, service, and agricultural activity and the underutilization of national production components. This will drive greater poverty and unemployment and thus lower levels of consumption, as well as higher prices under the monopoly advantages and restrictive measures of developed countries.

4- Industry is undergoing a fundamental change in industrialized countries as they have become monopoly countries for the production of knowledge-intensive goods, particularly medicines.

5- The intellectual property protection clause is one of the most dangerous things facing Iraq, as well as a breach of freedom because it would represent a monopoly on the highly intelligent factor in the production process, which would deprive these countries of access to hightechnology, cheap goods close to their markets.

6- The Convention is only a means of generating monopoly revenue from poor countries through the higher cost of patents and copyright and strengthening the influence of global companies in the field of drug monopolies.

\section{RECOMMENDATIONS}

1- Seek to create adequate social security networks, formulate consumer protection laws and uphold the importance and role of the State to achieve such protection. review trade, investment, and exchange rate laws and reform legal, administrative, and financial systems. Priority should be given to strengthening the functional structure and combating economic crime and industrial and commercial fraud. 


\section{Volume: 12, Issue: 1, January-March 2022}

2- Support, protection, and Statesponsored domestic pharmaceutical industries and develop appropriate policies and market research to counter the negative effects of the WTO Convention and intellectual property protection laws. and the establishment of research and development centers to control drug technology, which will lead to capacity development to enhance competitive advantage, taking into account the importance of improving the quality and quality of products, their technical specifications, and their alignment with global changes.

3- Structural changes in production lines, production technology, and pharmaceutical marketing outlets, requiring financial investment and training of research and development cadres in the pharmaceutical industry.

4- Activating the role of pharmaceutical control and registration in preparing requirements for good manufacturing methods, including ensuring the safety and health of individuals at risk. Invalid medicines may be produced and marketed, creating a negative consumer impression about the quality of local medicines.

5- Giving economic information a large role and space to identify and disclose drugs, promising the crime of drug fraud as an economic misdemeanor to undermine the security of the individual, society, and the economy. This is reported in the media through a statement of the laws on industrial and commercial drug fraud, the establishment of a record of criminal precedents, the enforcement of punishment, and the enforcement of penal sanctions, as well as financial sanctions.

6- To promote the role of the Pharmacists' Association, security agencies, and civil society organizations in consumer protection, as well as the identification of import and distribution outlets by specialists from the global establishment; 7- When the State wishes to use the compulsory license, it must prove that the parent company refuses to grant the license for reasonable fees and that the parent company carries out non-competitive activities in the country concerned. 


\section{REFERENCES}

1- Oman, Charles, Globalization and Regionalization, The Challenge For Developing Countries OCED, 1994, P 27.

2- Thurow Lester, The Future Of Capitalism, Penguin Books, New York, 1997, p 128.,

3- Meed, james, The Balance Of PAY MENT, LONDON, Oxford University Press 1951.

4- Schossudvsky, Michel, The Globalization Of Poverty Impacts Of Imf And World Bank

Reform, Penang Malaysia, The Third World Network, 1999.P 71-72.

5- Kevin, Clearer, The Impact Of Price And Exchange Rate Policies On Agrieulture In SubSahara Africa, World Bank, 1985, Staff-Working Paper No. 728.

6- Mohidin, Mahmoud, Globalization and Economic Governance, An Egyptian Perspective, Arab Monetary Fund, Abu Dhabi, 2001, pp. 274-280.

7- Jamaili, Hamid, IMF Between Past Policy Failures and Future Crisis Challenges, Mother of Battle Volume, Year 5, No. 18, 1999, 17.

8- Abdel Hay, Walid Dhulum, Vow of Globalization, Dar Vanguard, Cairo, 1999, p. 228.

9- Birch, dr. Mahmoud Riad and Marzouk, dr. Noble Privatization, Prospects and Dimensions, Contemporary Thought House, Beirut, 1999, p. 89.

10- (For further discussion of these issues, see Subramanian and Bad-El-Latif 1997. 11- ESCWA, Evaluation of Privatization Programmes in the ESCWA Region, United Nations, New York, 1999, pp. 13.14.

12- Blue, dr. The Beauty of Debt, the Relationship of Trade to Investment Procedures and its Implications for the Interests of Developing Countries, ESCWA, United Nations, New York, 2001, p. 4.

13- The Traveller, Mahmoud Khalid and Fahd Isser Yassin, under Al-Awlami, What Will the South Gain from the New World Trading System, Wisdom Magazine, No. 16, Baghdad, 2002 , p. 67.

14- Shilbi, Ala, Convention on Trade Aspects of Intellectual Property Rights and its Implications for Arab States, ESCWA, United Nations, New York, 2001, pp. 2.3.

15- Dr. Hodgins. Hatem, Sami Afifi, Studies in International Economics, Egyptian House of Lebanon, Al Farouq Press, Cairo, T5, February 2000, $\quad$ S87. 16- General Secretariat of the General Federation of Arab Chambers of Commerce, Industry and Agriculture, Journal of Economic Papers, No. 15, 2000, p. 250. 17- Al-Quraishi, Reza, Intellectual Property Rights at the World Trade Organization and 


\section{Volume: 12, Issue: 1, January-March 2022}

Their Implications for Arab Countries, Arab Affairs Journal, No. 103, September 2000, pp. 208-209.

18- On behalf of the Convention on the Protection of Intellectual Property and its Impact on the Pharmaceutical Industry in Palestine, Arab Economic Research Journal, Year 9, No. 22, 2000, p. 14.

19- Zeini, Muhammad Ali, Past and Present Iraqi Economy and Future Options, Angel Art,

Literature and Publishing House, first edition, Baghdad, 2009.

World Health Organization (WHO) 